\title{
ReMOTE SENSING OF ASPEN CHANGE IN Northern Yellowstone National Park
}

\author{
ERIC J. LARSEN $\downarrow$ DEPARTMENT OF GEOSCIENCES \\ OREGON STATE UNIVERSITY $\downarrow$ CORVALLIS
}

\author{
WILLIAM J. RIPPLE \\ ENVIRONMENTAL REMOTE SENSING APPLICATIONS LABORATORY (ERSAL) \\ DEPARTMENT OF FOREST RESOURCES \\ OREGON STATE UNIVERSITY $\downarrow$ CORVALLIS
}

\begin{abstract}
$\downarrow$ ABSTRACT
We combined remote sensing with field surveys to compare the status of aspen on Yellowstone National Parks' (YNP) northern range with adjacent areas in the Gallatin and Shoshone National Forests. Photographic enlargements from historic aerial photographs were paired with same scale enlargements of 1992 aerial photos to quantify the change in aspen and conifer canopy coverage in the study areas. In YNP aerial photographs from the years 1954 and 1992 were used to quantify change while photographs from 1958 and 1992 were used in the Shoshone and Gallatin National Forests. Vegetation was classified as either aspen, conifer or steppe and changes in canopy coverage were calculated for the time period. The data are being aggregated by area and changes in YNP conditions are being compared to changes in the Gallatin and Shoshone National Forests. In the field $2 \times 30$ meter transects provided data on aspen overstory density, size class, degree of browsing pressure on ramets, and bark stripping of mature trees. The field transects also provided information on the size and intensity of conifer encroachment in aspen stands. Aspen cores are being collected to provide age information. Our data set is not yet complete and the results must be considered preliminary but we are observing differences
\end{abstract}

between YNP and the adjoining areas. Based on the diameter at breast height (dbh) measurements collected in the 1997 field season, aspen in the Clarks Fork of the Yellowstone and Sunlight basins (Shoshone National Forest) have a younger and more varied age class distribution than YNP's northern range. Over $99 \%$ of overstory aspen measured in the YNP transects are in the largest size class $(>20 \mathrm{~cm} \mathrm{dbh})$, a significantly higher percentage than in either the Clarks Fork or Sunlight Basin areas. Mortality as measured by the ratio of dead to live aspen stems was greatest in the Clarks Fork area, where dead trees comprised 36\% of the total number of aspen. Conifer encroachement is greater in the Shoshone National Forest than YNP but a large percentage of conifers in all study areas are in the smallest size class. Ramet densities averaged 4067-5730 shoots/ha in YNP and the Shoshone National Forest, comparable to other undisturbed stands in the Rocky Mountains. We present here results primarily from the 1997 field season. The remaining field work is scheduled to be completed during the 1998 field season, including all of the work in the Gallatin National Forest. The full results will be available upon completion of data analysis and the integration of the remote sensing and field data. 


\section{INTRODUCTION}

Quaking aspen (Populus tremuloides) is an adaptable species that is the most widely distributed tree in North America. Aspen occurs but is not a dominant cover type in Yellowstone National Park (YNP) and the adjacent Shoshone and Gallatin National Forests. Despite its limited distribution in this area, aspen is considered an ecologically significant species. Aspen is one of the few deciduous species that inhabits the greater Yellowstone area. It provides habitat for numerous bird species, supports a variety of plant associations, and is used as browse by several ungulate species (Kay 1990, Romme et al. 1995, St. John 1995). Aspen is also prized for its fall foliage and aesthetic appeal, which is an important quality for the thousands of yearly visitors to YNP.

In YNP, aspen principally occurs on the northern range which is the large elk wintering area in the valleys of the Yellowstone, Gardiner, and Lamar Rivers. Despain (1990) mapped YNP vegetation from 1:15,840 scale color aerial photos and field surveys and estimated that aspen occupied approximately $2-3 \%$ of the northern range landscape. Aspen occurs in small stands on midslope benches and in strips along the conifer/steppe ecotone. Aspen are rare in the riparian zones of the Yellowstone and Lamar Rivers although it is present along the banks of smaller tributaries such as Geode Creek.

Aspen has been declining in abundance on the northern range in this century and a debate has developed over the causes and consequences of this decline (Houston 1982, Kay 1990, Romme et al.1995, Tyers 1981). Much of this debate has revolved around factors thought to be contributing to the decline. These include the roles of ungulate browsing, fire suppression, climate fluctuation, and the market hunting era of the 1870's (Meagher and Houston in press, Romme et al. 1995).

Although rare on the high plateaus immediately to the south of the northern range, aspen does occur as a nondominant cover type in the Gallatin and Shoshone National Forests to the north and east of YNP. This study is designed to obtain a more complete ecological picture of the status of aspen by contrasting conditions on the northern range with adjacent areas within the Gallatin and Shoshone National Forests.

\section{STUDY AREA}

There were several areas selected for this study. Within YNP, the study area is the northern range, the 100,000 hectare (ha) wintering grounds for the parks' largest elk herd (Houston 1982). That portion of the northern range which lies in the Gallatin National Forest is also included in the study. This includes areas of the Gardiner Ranger District from the park boundary extending northward to Dome Mountain. We chose two study areas within the Shoshone National Forest. The Sunlight Basin was selected since it is an important elk wintering area that is in close proximity to the northern range. The basin of the Clarks Fork of the Yellowstone River (above Sunlight Creek confluence) provides data in an area that is not heavily utilized by ungulates as winter range.

\section{$\uparrow \quad$ Objectives}

following:

The objectives of the study are the

1.) Map changes in canopy coverage of aspen and conifers on randomly selected sites within the study areas.

2.) Use the aerial photo data in conjunction with field surveys to compare vegetation status and change on YNP's northern range with similar areas in the Gallatin and Shoshone National Forests.

3.) Attempt to determine the causes for any observed differences of aspen status or change between YNP and the adjacent National Forests.

\section{METHODS}

Aspen stands in YNP and the Shoshone National Forest were mapped from a set of 1:24,000 color infrared (CIR) aerial photographs taken in 1988. These photographs were chosen because of the ease in which aspen can be differentiated from conifer in the CIR portion of the electromagnetic spectrum. A $1.0 \times 1.5 \mathrm{~cm}(240$ meter x 360 meter on the ground) rectangular grid was placed on each photo and each cell was identified as either containing or not containing aspen. A random selection of 100 northern range cells and 40 each from the Clarks Fork and the 
Sunlight Basin was made from only those grid cells containing aspen. These cells formed the basis of sampling aspen conditions in the study areas (the inventory and site selection for the Gallatin National Forest is still in progress).

For the remote sensing portion of the study, historic aerial photographs were paired with 1992 aerial photos to analyze change in aspen and conifer canopy coverage over time. In YNP, black and white photographs taken in 1954 were paired with a 1992 natural color set. In the Shoshone and Gallatin National Forests, 1958 black and white aerial photos were matched with 1992 natural color photos. The time periods were chosen by pairing the most recent photos with the most closely matched historic aerial photography set between YNP and the two National Forests.

For each randomly chosen grid cell, photographic enlargements to 1:5000 scale were obtained from both the 1954 (or 1958) and the 1992 aerial photographs. A dot grid was placed over the chosen grid cell and vegetation cover was classified as conifer, aspen, or steppe using a mirror stereoscope. If any portion of the dot touched the canopy of an aspen or conifer it was counted as a "hit" of that vegetation type. Vegetation change was determined by comparing the number of canopy hits in the 1950's aerial photographs with the hits on the 1992 photographs. Average change per year was then calculated to allow comparison between YNP and the National Forests.

Change per year in aspen coverage are being analyzed both statistically and geographically. The results are being grouped by study area and an Analysis of Variance (ANOVA) will be utilized along with Multiple Range Testing procedures to look for significant differences among groups. Maps will be developed showing the change in aspen cover by time period.

In the field, 2 meter $\times 30$ meter transects were conducted in each sampled stand, running from the edge of the stand toward the centroid. An aspen stand was defined as a group of trees within 30 meters of each other. Simply, if a tree was further than 30 meters from any other tree in the stand, it was not a part of that stand. Further, a stand was defined as containing at least two living aspen trees. If the stand consisted of only two trees, the transect was located at the midpoint between them and extended toward each tree. If the stand consisted of three or more trees, a random start direction was chosen and the transect was run from that edge towards the centroid. In the rare case that only one living aspen tree was included in the $2 \times 30$ meter transect, the transect was expanded (for tree counting only) to either $6 \times 30$ or $30 \times 30$ meters so as to include at least one more living tree.

Given the above criteria, each $240 \times 360$ meter grid cell could potentially contain several aspen stands. If a cell contained multiple stands, one aspen stand was randomly chosen within the cell and a single transect was established. The following information was collected in each transect:

1.) Elevation, topographic position, slope, and aspect were recorded for each site. The Universal Transverse Mercator (UTM) coordinates for the start of the transect was recorded.

2.) The density and diameter at breast height (dbh) of aspen trees observed. An aspen tree was defined as being greater than two meters tall and was further differentiated into "replacement" and "nonreplacement" trees (Kay 1993). A replacement tree was greater than two meters tall but less than five $\mathrm{cm} \mathrm{dbh}$. A non-replacement tree was greater than two meters tall and also greater than five $\mathrm{cm} \mathrm{dbh}$.

3.) The amount of bark stripping on aspen trees was measured. This was calculated as the percentage of black corky bark (characteristic of elk browsing) that occurred on the bottom two meters of the tree. The trees were visually inspected and bark stripping was classified as either low (0-33\%), medium $(34 \%-66 \%)$, or high $(67 \%-100 \%)$ levels of damage.

4.) We recorded the density of standing dead, recent dead (leaves still on tree), and fallen aspen in the transect.

5.) We recorded the density and dbh of conifers in the transect.

6.) We recorded the density of browsed, unbrowsed and dead ramets in the transect. Ramets were defined as those aspen stems less than two meters tall.

7.) To estimate the age, we used an increment borer to obtain two cores of stand dominant aspen in each transect. This was not always feasible since a large percentage of aspen greater than $20 \mathrm{~cm}$ dbh in this 
area are infected by heart rot and obtaining cores was not possible. The aspen were cored at a height of one meter.

\section{PROGRESS REPORT}

This study is still in progress and we are only presenting findings for a portion of our stated objectives, primarily results from the field transects. A full report will follow upon completion and analysis of data from the 1998 field season.

An illustration of the historic aerial photo comparison is given in Figure 1. This site is located long the Lamar River (YNP) upstream from the Soda Butte Creek confluence. On this particular site, aspen canopy coverage declined $80 \%$ from 1954 to 1992 (from a total of 54 canopy hits in 1954 with the dot grid to 11 canopy hits in 1992). This site shows the greatest decline of all YNP sites analyzed to date and is included to illustrate how aerial photo pairs can be utilized to measure change over time. Full results of the aerial photo comparison will be available once ground truthing is completed in 1998.

A total of 71 transects were established in the 1997 field season. These included 41 within YNP, 18 in the Sunlight Basin and 12 in the Clarks Fork area. In each transect, the dbh of each aspen and conifer was tallied. Table 1a illustrates the number of stems in each size class for the study areas. It shows that aspen stands in YNP have a greater percentage of overstory stems in the largest size class $(>20 \mathrm{~cm} \mathrm{dbh})$ than the Shoshone study areas. Table $1 \mathrm{~b}$ illustrates stand level data, specifically how many stands contain stems in each size class (note that since many stands contain more than one size class the percentages may exceed $100 \%$ ). The Clarks Fork area has a greater percentage of stands containing aspen in the smaller dbh classes than either YNP or the Sunlight basin.

Figure 2 illustrates aspen stand composition and mortality in each of the study areas. The percentages are based on the total number of aspen and conifer stems counted in the transects. Our preliminary data set indicates that live aspen trees comprise less than $50 \%$ of the total stem count in aspen stands in both the Clarks Fork and Sunlight basin study areas. The Clarks Fork area also has the greatest percentage of standing dead stems $(26 \%)$ in any study area. If one considers only aspen stems, standing dead trees comprise $36 \%$ (48 dead out of 135 total stems) of the total in the Clarks Fork area. Considering only aspen stems, YNP contains 26\% (50/194) standing dead aspen and the Sunlight basin contains $29.4 \%$ (48/163). By comparison, Krebill found that dead standing aspen formed $42 \%$ of total stems in the Gros Vente River drainage in a 1972 study.

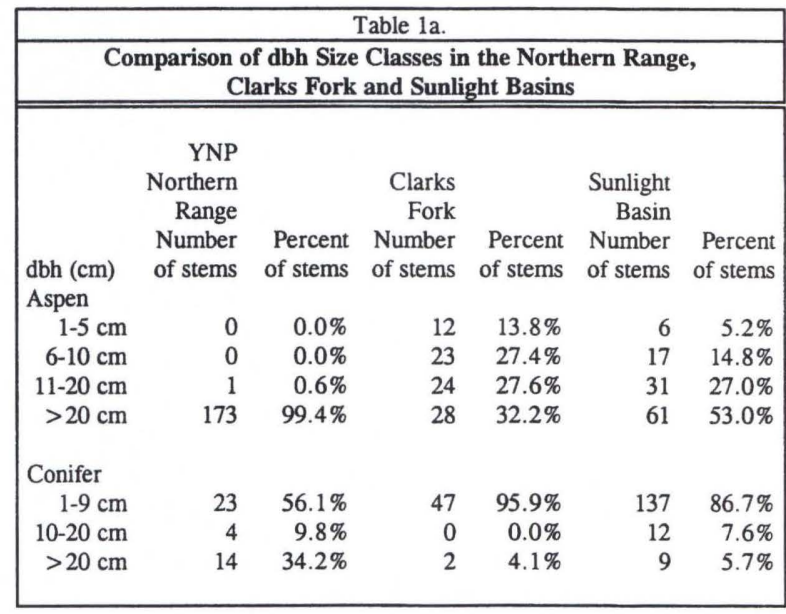

\begin{tabular}{|c|c|c|c|c|c|c|}
\hline \multicolumn{7}{|c|}{ Table $1 \mathrm{~b}$} \\
\hline \multicolumn{7}{|c|}{$\begin{array}{c}\text { Comparison of the Percentage of Aspen Stands } \\
\text { Containing Stems in Various Size Classes } \\
\end{array}$} \\
\hline & \multicolumn{2}{|c|}{$\begin{array}{l}\text { YNP \% of stands } \\
\text { with stems in this } \\
\text { size class } \\
\text { ( } \mathrm{n}=41 \text { stands) }\end{array}$} & \multicolumn{2}{|c|}{$\begin{array}{l}\text { Clarks Fork \% of } \\
\text { stands with stems } \\
\text { in this size class } \\
\text { ( } n=12 \text { stands) }\end{array}$} & \multicolumn{2}{|c|}{$\begin{array}{l}\text { Sunlight Basin } \% \text { of } \\
\text { stands with stems } \\
\text { in this size class } \\
\text { ( } \mathrm{n}=18 \text { stands) }\end{array}$} \\
\hline $\mathrm{dbh}(\mathrm{cm})$ & $\begin{array}{l}\text { Number } \\
\text { of stands }\end{array}$ & $\begin{array}{l}\text { Percent } \\
\text { of stands }\end{array}$ & $\begin{array}{l}\text { Number } \\
\text { of stands }\end{array}$ & $\begin{array}{l}\text { Percent } \\
\text { of stands }\end{array}$ & $\begin{array}{l}\text { Number } \\
\text { of stands }\end{array}$ & $\begin{array}{l}\text { Percent } \\
\text { of stands }\end{array}$ \\
\hline Aspen & & & & & & \\
\hline $1-5 \mathrm{~cm}$ & 0 & $0.0 \%$ & 3 & $25.0 \%$ & 2 & $11.1 \%$ \\
\hline $6-10 \mathrm{~cm}$ & 0 & $0.0 \%$ & 5 & $41.7 \%$ & 5 & $27.8 \%$ \\
\hline $11-20 \mathrm{~cm}$ & 1 & $2.4 \%$ & 8 & $66.7 \%$ & 16 & $88.9 \%$ \\
\hline$>20 \mathrm{~cm}$ & 41 & $100.0 \%$ & 10 & $83.3 \%$ & 16 & $88.9 \%$ \\
\hline \multicolumn{7}{|l|}{ Conifer } \\
\hline $1-9 \mathrm{~cm}$ & 8 & $19.5 \%$ & 4 & $33.3 \%$ & 16 & $88.9 \%$ \\
\hline $10-20 \mathrm{~cm}$ & 3 & $7.3 \%$ & 0 & $0.0 \%$ & 5 & $27.8 \%$ \\
\hline$>20 \mathrm{~cm}$ & 7 & $17.1 \%$ & 2 & $16.7 \%$ & 5 & $27.8 \%$ \\
\hline
\end{tabular}

Conifer encroachment into aspen stands is greatest in the Sunlight basin where $61 \%$ of the total number of surveyed stands contained conifers. In comparison, $27 \%$ of YNP stands and 33\% of Clarks Fork stands surveyed contained conifers. Care should be exercised when interpreting the graphs of Figure 2 regarding the conifer percentages. For example, in the Sunlight Basin conifers comprise $49 \%$ of the total stem count but this percentage is greatly influenced by four stands ( $n=18$ stands) that were heavily invaded. These percentages may change significantly when the full data set is obtained. Considering only aspen stands that 
contain conifers, YNP has an average density of 488 conifer stems per ha ( $S D=263, n=11$ stands). In the Sunlight Basin conifer density averaged 1,562 stems/ha within invaded aspen stands $(\mathrm{SD}=1,620$, $\mathrm{n}=11$ stands). Based on the limited sample collected so far, the Clarks Fork area averaged 2,041 conifer stems/ ha within invaded aspen stands $(\mathrm{SD}=1,620, \mathrm{n}=4)$. Referring to Table $1 \mathrm{a}$, it can be seen that a large percentage of invading conifers are less than $10 \mathrm{~cm}$ dbh in each of the study areas. Table $1 \mathrm{~b}$ gives a better indication of the encroachment of conifers on a per stand basis. The Sunlight basin has the highest percentages of conifer encroachment in each size category, especially in the smallest conifer class.

Ramet densities were tallied in each of the transects with measurements ranging from 0 to 20,000 shoots/hectare (Figure 3). YNP averaged 4,067 ramets $/$ ha $(\mathrm{SD}=4,083$ ), the Clarks Fork area averaged 5,730 ramets/ha $(S D=5,235)$ and the Sunlight basin averaged 5,375 ramets/ha $(\mathrm{SD}=$ 5,959). By comparison, Schier (1975) found between 2,298 and 7,166 ramets per hectare while Bartos and Mueggler (1982) recorded densities from 1,399-4,201 per hectare in a northern Utah study. Mueggler (1989) suggested that aspen stands with less than 1,235 ramets per hectare (500/acre) might have difficulty replacing themselves.

Each ramet was further inspected for signs of browsing. The highest percentage of browsed ramets occurred within YNP where 89.6\% (986 browsed out of 1100 observed ramets in transects) showed evidence of browsing. The Sunlight Basin followed with $85.6 \%(523 / 611)$ and in the Clarks Fork $76.7 \%(247 / 322)$ had evidence of ungulate browsing.

In the summer of 1998 we will conclude the field portion of the project, including all of the sampling within the Gallatin National Forest. The additional field work will provide both transect information and the necessary ground truthing for the temporal aerial photo comparison. Complete results from the aspen cores and the aerial photo change analysis will be presented upon completion of the field portion of the study and the integration of the data sets. We expect our results will provide a better understanding of aspen dynamics over a wide area of northern Yellowstone National Park and the surrounding National Forests. In addition it will provide geographically precise data as to where the most significant changes in aspen canopy coverage have occurred. The results should be beneficial to resource managers to assist in the development of ecosystem based management plans.

\section{$\downarrow$ ACKNOWLEDGMENTS}

This research has been supported by a grant from the University of Wyoming - National Park Service Research Center. Douglas Houston provided assistance in project development. Dale Bartos, Don Despain, Roy Renkin and Rob St. John assisted in the development of field sampling techniques. We thank Jerry Simon and Connie King of the Shoshone National Forest for providing access to aerial photographs and other records. We would also like to thank John Varley, Lee Whittlesley, Susan Kraft and the staff of the YNP archives for their assistance while working within YNP. We extend special thanks to Phil Perkins for the use of the aerial photo collection at YNP's Fire Cache.

\section{LITERATURE CITED}

Bartos, D.L. and W.F. Mueggler. 1982. Early succession in aspen communities following clearcutting of aspen communities in northern Utah. Journal of Range Management. 35(6):764-768.

Despain, D.G. 1990. Yellowstone Vegetation. Consequences of environment and history in a natural setting. Roberts Rinehart, Boulder, CO.

Houston, D.B. 1982. The Northern Yellowstone Elk: Ecology and Management. Macmillan, New York, NY.

Kay, C.E. 1990. Yellowstone's northern elk herd: A critical evaluation of the "Natural Regulation" paradigm. $\mathrm{PhD}$ dissertation, Utah State University, Logan UT.

Kay, C.E. 1993. Aspen seedlings in recently burned areas of Grand Teton and Yellowstone National Parks. Northwest Science 67(2):94-104.

Krebill, R.G. 1972. Mortality of aspen on the Gros Vente elk winter range. USDA Forest Service Research Paper INT-129. 16 pp. 
Meagher, M.M and D.B. Houston. In press. Yellowstone and the biology of time. University of Oklahoma Press, Norman, OK.

Mueggler, W.F. 1989. Age distribution and reproduction of intermountain aspen stands. Western Journal of Applied Forestry. 4(2):41-45.

Romme, W.H., M.G. Turner, L.L Wallace, J.S. Walker. 1995. Aspen, elk and fire in northern Yellowstone National Park. Ecology 76(7):2097-2106.
Schier, G.A. 1975. Deterioration of aspen clones in the Middle Rocky Mountains. USDA Forest Service Research Paper INT-170. $14 \mathrm{pp}$.

St. John, Robert. 1995. Aspen stand recruitment and ungulate impacts: Gardiner Ranger District, Gardiner, Montana. MS Thesis, University of Montana, Missoula, Montana.

Tyers, Daniel. 1981. The condition of the northern winter range in the Yellowstone National Park - a discussion of the controversy. MS thesis, Montana State University, Bozeman, MT. 

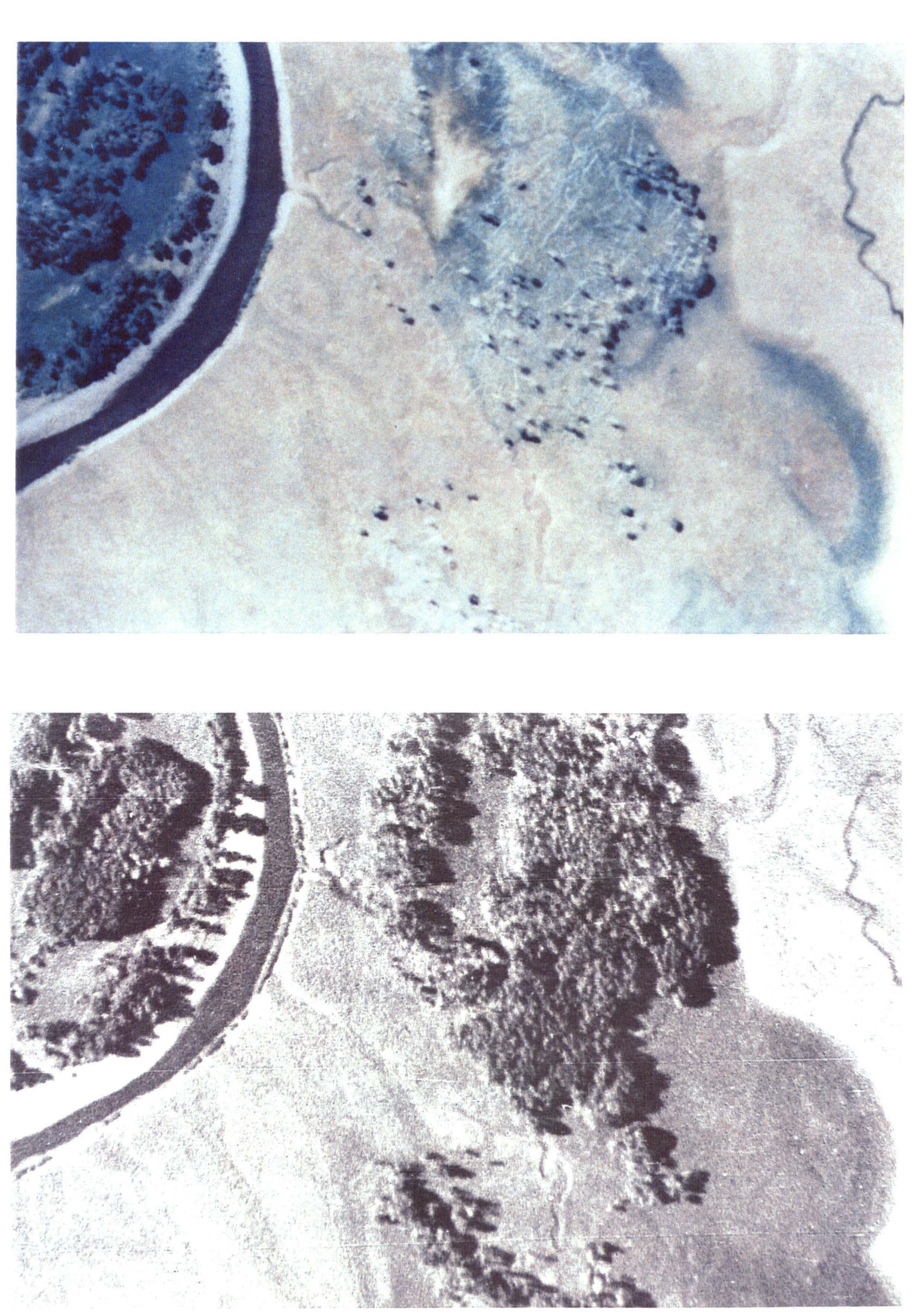

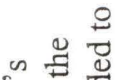

逍产要

ज

뎔 물

त

융 용

동

岕

正过

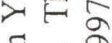

ธี $\frac{\mathrm{a}}{\mathrm{a}}$

荧怘导

\% $:$

吉守

ธี

ิํำ สี

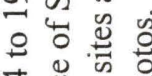

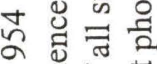

出案峲菏

ठ ठ 용

过艺

‥ ह

芯芯芯㤩

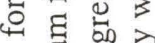

일

政

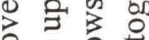

웡

त

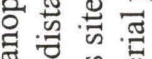

ฮु

苛寻它

के क

허읭

글

os $₫$.

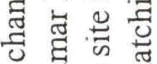

言 品

品藏

tٓ

ज्ञ

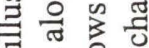

द वृ की

등 융

행으웡

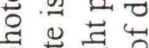

क ज

总吾㤩

出晜

ह 然

- 2 向

踏

正 
Figure 2a

Aspen Stand Composition and Mortality on the Northern Range of Yellowstone National Park, WY.

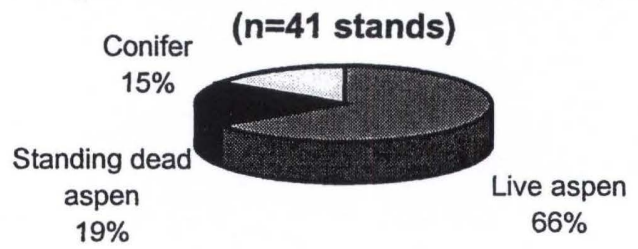

Figure 2b

Aspen Stand Composition in the Clarks Fork of the

Yellowstone River Basin, WY.

( $n=12$ stands)

Conifer

$27 \%$

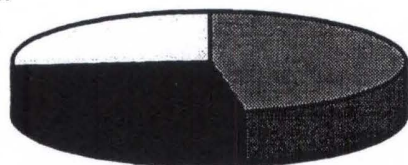

Live aspen

$47 \%$

Standing dead

aspen

$26 \%$

Figure 2c

Aspen Stand Composition and Mortality in the Sunlight

Basin, WY.

( $n=18$ stands)

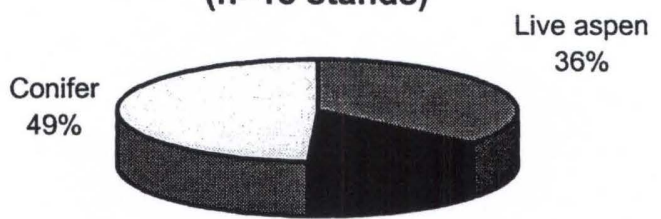

Standing dead

aspen

$15 \%$ 


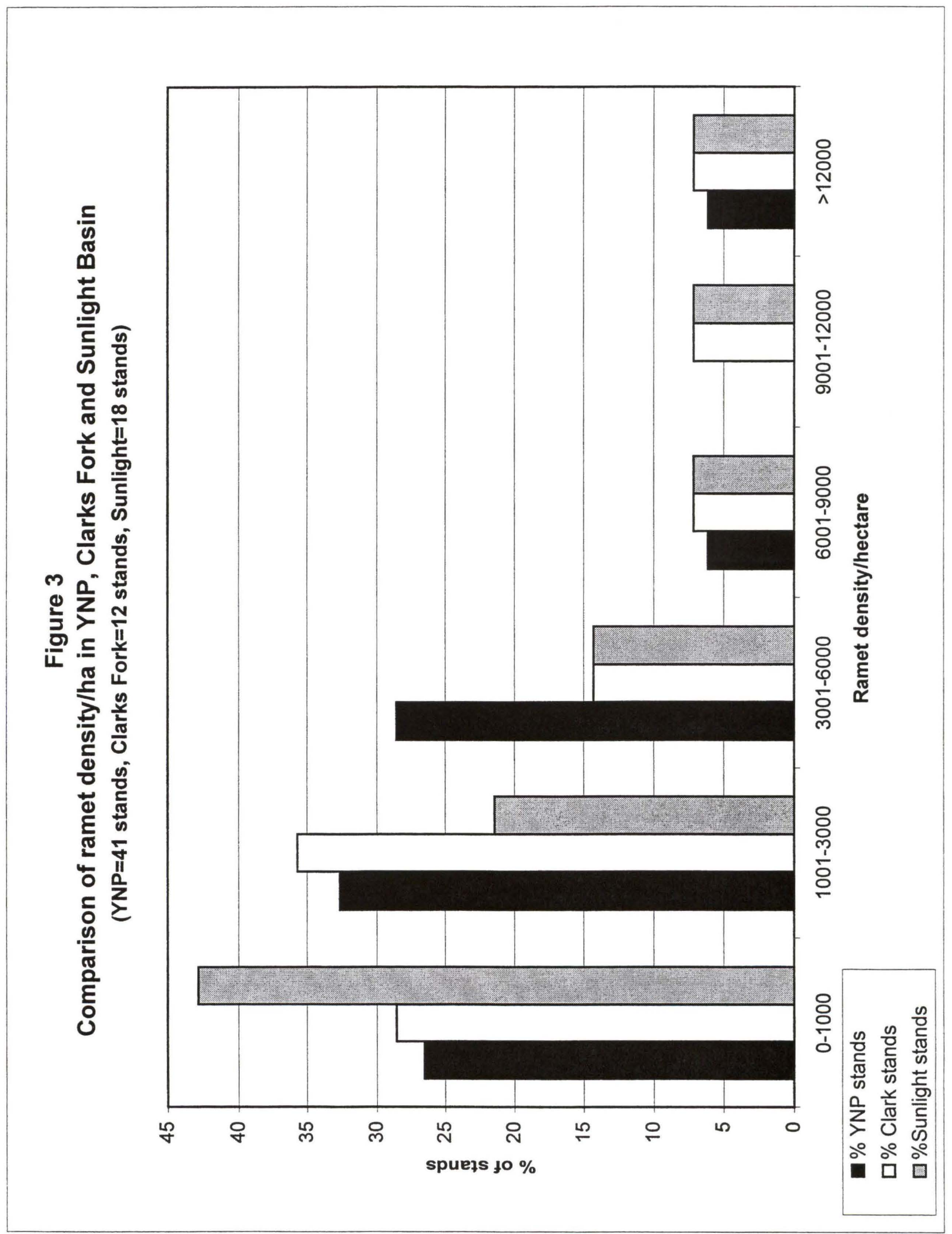

